\title{
ACCURACY OF RISANTO'S FORMULA COMPARED WITH JOHNSON'S TO ESTIMATE FETAL WEIGHT IN OVERWEIGHT MOTHERS
}

\author{
Fifi Noviana, Diah Rumekti, Risanto Siswosudarmo
}

\begin{abstract}
Background: Estimated fetal weight (EFW) is becoming important because it is used as a guidence for determining mode of delivery. The use of estimated fetal weight based on fundal height has been widely used, but its use in overweight pregnant mothers was still limitted.

Objective: To compare the accuracy of Risanto's and Johnson's formulas in estimating fetal weight based on fundal height in overweight mothers.

Method: It was a cross-sectional study, conducted from March 2013 to July 2014 in Sardjito hospital and hospital networks. All pregnant mothers meeting the elligibility criteria were used as study subjects. Overweight mother was defined based on body mass index (BMI) and skinfold thickness on suprailiaca region. Fundal height (FH) was measured from the symphysis pubis to the midle of the upper border of the pregnant uterus. Accuracy of Risanto's and Johnson's formulas was dtermined by comparing the difference between EFW and actual infant birth weight (AIBW). Paired t-test was used for statistical analysis.

Result and Discussion: There were 395 overweight pregnant mothers fulfilling the inclusion and exclusion criteria. The mean AIBW was $3060.3 \pm 322.5$ grams (ranged from 2360 to 3940 grams). The mean EFW using Risanto formula (R_EFW) was $3095.8 \pm 320.3$ grams (ranged from 2370 to 3870 grams ) while that of Johnson (J_EFW) was $3273,7 \pm 378,1$ grams (ranged from 2325 to 4185 grams). The mean difference between between AIBW and $\triangle R$ ) EFW (was 109.85 grams while that of AIBW and J_EFW J) (was 198.41 grams $\Delta$. RIt was clear that significantly smaller $\Delta \mathrm{J}$ than with the mean difference minus 88.56 grams $(95 \% \mathrm{Cl}-98.76$ to -78.35 ; $p$ value 0.000 ).
\end{abstract}

Conclusion: The new Risanto's formula was more accurate to estmate infant birth weight than Johnson's in overweight mothers.

Keywords: Risanto's and Johnson's Formulas, Estimated Fetal Weight, Overweight Mothers.

\begin{abstract}
ABSTRAK
Latar belakang: Taksiran berat janin (TBJ) adalah penting karena dapat digunakan sebagai petunjuk untuk menentukan jenis kelahiran. Penggunaan pengukuran tinggi fundus uterus untuk menentukan TBJ sudah luas dipakai, tetapi penggunaannya pada ibu dengan berat badan berlebih masih terbatas.

Tujuan: Untuk membandingkan ketepatan rumus Risanto dengan rumus Johnson dalam menentukan TBJ berdasar tinggi fundus uterus pada ibu dengan berat badan berlebih.

Metode: Dengan menggunakan rancangan potong lintang, penelitian ini dikerjakan selama lima bulan dari Maret sampai Juli 2014 dengan mengambil tempat di RS Sardjito dan jejaringnya. Semua pasien yang memenuhi kriteria kelayakan diambil sebagai subyek penelitian. Berat badan berlebih ditentukan berdasar indeks massa tubuh (IMT) dan ketebalan lipatan kulit di regio suprailiaka.Tinggi fundus dihitung dari simfisis
\end{abstract}

Department of Obstetrics and Gynecology Faculty of Medicine Universitas Gadjah Mada/

Sardjito Hospital Yogyakarta 
pubis sampai pertengahan puncak uterus gravidus menggunakan pita lentur. Ketepatan rumus Risanto dan Johnson dihitung berdasarkan perbedaan selisih antara berat bayi lahir (BBL) yang sebenarnya dengan TBJ berdasar rumus Risanto (TBJ_R) dan TBJ berdasar rumus Johnson (TBJ_J). Paired t-test digunakan untuk menghitung perbedaan rata-rata tersebut. Makin kecil perbedaan maka rumus makin akurat.

Hasil dan Pembahasan: Terdapat 395 ibu hamil dengan berat badan berlebih yang memenuhi kriteria kelayakan. Berat bayi lahir rata-rata adalah $3060.3 \pm 322.5$ gram (bervariasi dari 2360 sampai 3940 gram). TBJ_R rata-rata adalah $3095.8 \pm 320.3$ gram (bervariasi dari 2370 sampai 3870 gram) sedang TBJ_J adalah $3273,7 \pm 378,1$ gram (bervariasi dari 2325 sampai 4185 gram). Beda rata-rata antara $\triangle R$ ) BBL dengan TBJ_R (adalah 109.85 grams sedang beda rata-rata antara BBLSJ)denganadalah TBJ_J (198.41 grams. Nyata bahwa $\Delta R$ secara bermkana lebih kecil dibanding $\Delta \mathrm{J}$ dengan beda rata-rata (mean difference) minus 88.56 gram $(95 \% \mathrm{Cl}$ -98.76 sampai -78.35; nilai p 0.000).

Kesimpulan: Rumus Risanto lebih tepat (akurat) dibanding rumus Johnson dalam menentukan TBJ pada ibu dengan berat badan berlebih.

Kata kunci: Rumus Risanto, Rumus Johnson, Taksiran Berat Janin, Berat Badan Ibu Berlebih.

\section{INTRODUCTION}

Estimating fetal weight is becoming important because some problems encountered during labor and delivery might come from error in determining fetal weight especially for extremely large baby. Estimated fetal weight (EFW) might be predicted by maternal abdominal palpation, which is cheap, simple, could be done without any sophysticated instrument and could be done by all delivery attendents, with high accuracy.

The most popular method is by measuring symphisis fundal height (FH). As the $\mathrm{FH}$ growth chart differs from one group of population to another it was important to develop a formula in a specific ethnic, popupation or race. By using $B M I$, middle upper arm circumferenece (MUAC) and parity, the sensitivity of the $\mathrm{FH}$ growth chart in predicting newborn being SGA is improved, mostly at the expense of specificity. ${ }^{1}$

Abdominal palpation is a routine procedure carried out during antenab ntal care to examine intrauterien fetal lie, attitude, presentation and to estimate fetal weight especially during the last trimester. It is influenced greatly by the degree of obesity and fat disposition in the subcutaneous tissue. To determine a more accurate degree of obesity in a pregnant woman in addition to calculating the BMI, a measurement of skinfold thickness is now widely used. It can be done in the biceps and triceps muscles which shows a good correlation with fat assessment in the obese pregnant women. ${ }^{2}$ In this study we used skinfold caliper for assessing the thickness of skinfold at the suprailiaca region. It was not as good as skinfold at subscapular, trisceps and biceps regions, but this was the instrument we found.

FH measurement is a simple and inexpenssive procedure that is widely used during antenatal care. FH measurement is not only used to determine fetal weight, but also used to predict small for gestaional fetus, multiple pregnancy and other fetal anomaly. ${ }^{3}$ It is subjectively influenced by the examiner but it has a high sensitivity to estimate fetal weight. ${ }^{4}$

One method to calculate the EFW by measuring $\mathrm{FH}$ was developed in the Department of Obstetrics and Gynecology of Sardjito Hospital, under the name of Risanto's Formula. ${ }^{5}$ Compared 
to Johnson formula, Risanto was more accurate with a mean difference 55,29 gram $^{6}$

\section{MATERIAL AND METHOD}

A cross sectional design was applied. The study was caried out from March 2013 to July 2014 in Sardjito hospital and its hospital networks. Those with singleton fetus, cephalic presentation, gestational age between 3742 weeks, alive fetus, delivered vaginall or abdominaly were recruited as study subjects. Pregnant mothers with certain fetal anomlies such as hidrocepalus, anenchephalus, fetal hidrop, or with polyhidramnion or oligohidramnion, intra abdominal mass were excluded.

Fundal height measurement was caried out by Resident in charge in the delivery room during the latent phase of labor or during the first stage. Mother was in supine position with both hips and knees joints flexed. In case of full bladder, she was asked to void. Fundal height was measured during no contraction using flexible non-elastic tape (sewing tape) from the symphisis pubis to the top of the uterine fundus. If the uterus was slanting, an assistant was asked to fix the uterus in the midline. Measurement was done twice with the inversed tape to avoid bias. If during the first 24 hours patients didn't give birth, then the new measurement was done. The baby was weighed during the first hour after delivery using the similar baby scale after calibrated, and the data were recorded using the provided forms. ${ }^{5}$

All pregant mothers with $\mathrm{BMI}$ more than normal (BMI $\geq 25 \mathrm{~kg} / \mathrm{m}^{2}$ ) were recruited for initial criteria. As $\mathrm{BMI}$ in the late pregnancy was no longer valid and reliable, then it was combined with skinfold thickness to get a more precise criteria for overweight mothers. Skinfold thickenss was measured with Personal Body Fat Tester caliper in the suprailiaca region. (Figure 1). Those who had skinfold thickess more than normal/ideal were considered as second criteria (Figure 2). ${ }^{7}$ Only mothers with $\mathrm{BMI} \geq 25 \mathrm{~kg} / \mathrm{m}^{2}$ and skinfold thickess above normal/ideal were classified as being overweight.

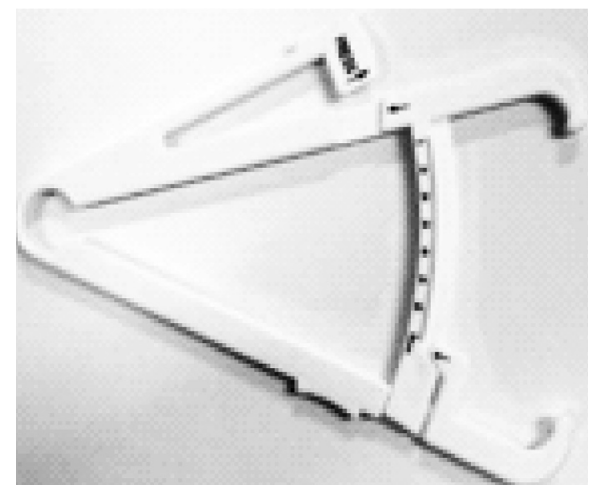

FIGURE 1. Personal Body Fat Tester Caliper

BOIJY FAI US MEASUREMENT CHART FOA WOMEN

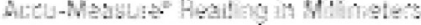

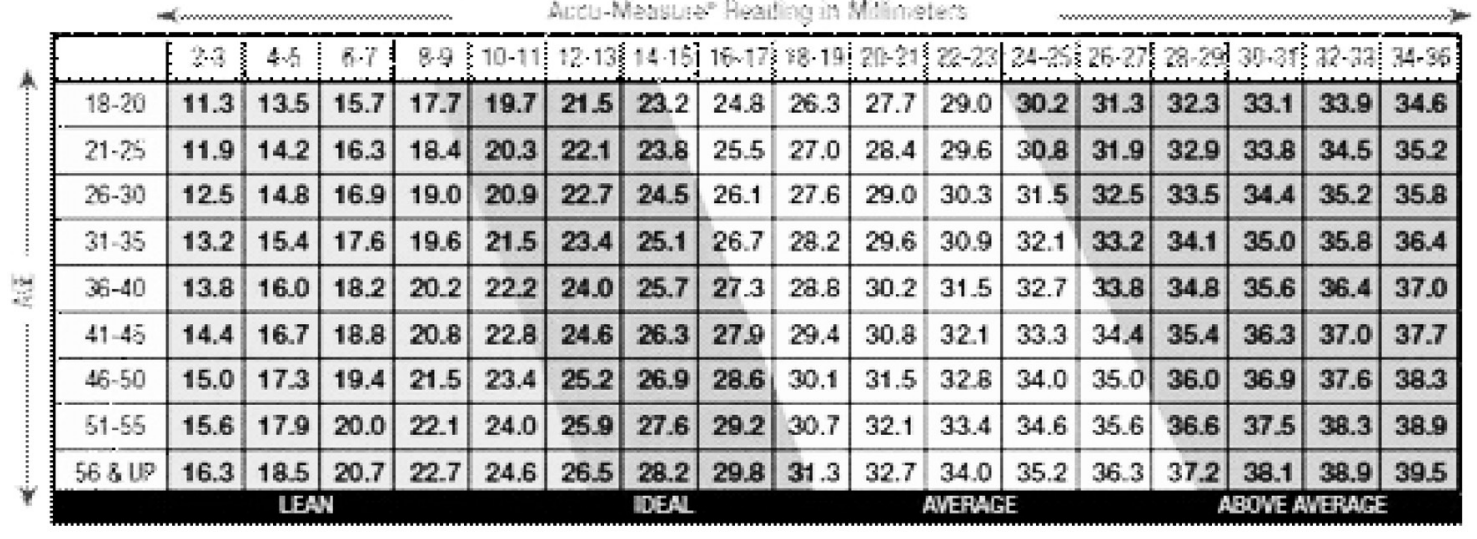

FIGURE 2. Interpretation of skinfold thickness 
EFW based on Risanto's formula (R_EFW) was calculated by the following formula: $R \_E F W=$ $125 \mathrm{X}-880$ grams, where $\mathrm{X}$ was $\mathrm{FH}$ in $\mathrm{cm} .(5) \mathrm{EFW}$ based on Johnson formula (J_EFW) was obtained from Johnson's formula namely J_EFW $=(F H-n)$ $x 155$ grams, where $n=11$ if the head was not engaged and $n=12$ if the head was engaged. ${ }^{8}$ All babies were weighed during one hour after delivery using similar baby scale after calibrated.

To determine which formula was more accurate to predict the AIBW, the difference between AIBW and $\triangle R$ ) EFWwas compared( with that of AIBW and J_EFW J). ( The smaller the difference the more accurate the formula. For that purpose paired t-test was used to test the mean difference between between $<0.05$ was considered to be statistically different.

\section{RESULT AND DISCUSSION}

During the study period, 395 pregnant mothers meeting the inclusion and exclusion criteria were recruited. The mean body weight was $66,55 \pm 7,64 \mathrm{~kg}$ ranging between $53 \mathrm{~kg}$ and $102 \mathrm{~kg}$, while their mean body height was $151,99 \pm 4,93 \mathrm{~cm}$ ranging from $138 \mathrm{~cm}$ to 170 $\mathrm{cm}$. All of them had $\mathrm{BMI}>25 \mathrm{~kg} / \mathrm{m}^{2}$. The mean BMI was $28.79 \pm 2.87 \mathrm{~kg} / \mathrm{m}^{2}$ with the minimum $25 \mathrm{~kg} / \mathrm{m}^{2}$ and maximum $37.3 \mathrm{~kg} / \mathrm{m}^{2}$. Their characteristics were shown in Table 1 as follows:

Tablel 1. Characteritics of study subjects

\begin{tabular}{lcc}
\hline Characteristics & $\mathrm{N}$ & Percentage \\
\hline Age (year) & 29 & \\
$<20$ & 301 & 76,3 \\
$20-35$ & 65 & 16,5 \\
$>35$ & & \\
Parity & 163 & 41,3 \\
Primigravida & 232 & 58,7 \\
Multigravida & & \\
BMI & 286 & 72,4 \\
Overweight & 109 & 27,6 \\
Obese & & \\
Skin fold thickness & 304 & 77,0 \\
Average & 91 & 23,0 \\
Overfat & & \\
\hline
\end{tabular}

Comparing the the EFW and the AIBW it seemed that EFW is always higher than the AIBW either calculated based on Risanto's formula for
Johnson formula. The differences were 109.8 grams higher for R_EFW and 192.7 grams higher for J_EFW. 
Table 2. Descriptive data for FH, IBW, R_EFW, $\Delta R$, J_EFW and $\Delta \mathrm{J}(\mathrm{N}=395)$

\begin{tabular}{lcccc}
\hline Variabel & Minimum & Maksimum & Mean & SD \\
\hline FH (cm) & 26 & 38 & 31,81 & 2,56 \\
IBW (gram) & 2360 & 3940 & 3060,3 & 322,5 \\
R_EFW (gram) & 2370 & 3870 & 3095,8 & 320,3 \\
$\Delta R$ (gram) & 0 & 790 & 109,8 & 104,3 \\
J_EFW (gram) & 2325 & 4185 & 3224,9 & 397,1 \\
$\Delta$ J (gram) & 0 & 720 & 192,7 & 138,9 \\
\hline
\end{tabular}

Study in Thailand showed that the use of Johnson's formula to estimate fetal weight gave an average of 227 grams higher compared to their actual infant birth weight. ${ }^{9}$ The same result was demonstrated by the our previous study conducted in Yogyakarta showing that Johnson formula was 107.4 grams higher and Risanto's formula was 86,2 grams higher. ${ }^{6}$

During pregnancy there was a weight gain as well as fat reserve. The average the fat deposit during 34-36 weeks was about $4.5 \mathrm{~kg} .{ }^{10} \mathrm{FH}$ in overweight and obese mothers was also higher compared to normal weight mothers so that the EFW should also be ajusted. ${ }^{11}$

To assess which formula was more accurate a paired $t$ test was accomplished to test their mean difference. It was shown that the difference between AIBW and R_EFW $(\triangle R)$ was smaller than the difference between AIBW and J_EFW $(\Delta \mathrm{J})$. It was 109.8 gram vs 192.7 grams and it was statistically significant (Table 3 ).

TABLE 3. Comparison between $\Delta R \Delta$ Jand (grams)

\begin{tabular}{ccccccc}
\hline & Mean & $S D$ & $\Delta$ Mean & \multicolumn{2}{c}{$95 \% \mathrm{Cl}$} & P Value \\
\hline$\Delta \mathrm{R}$ & 109,8 & 104,3 & 82,9 & 72,8 & 92,8 & 0.001 \\
$\Delta \mathrm{J}$ & 192,7 & 138,9 & & & & \\
\hline
\end{tabular}

Previous study conducted at the same place without considering degree of obesity showed that the difference between $\Delta R$ and $\Delta$ Jwas 55 . 29 grams (smaller than the recent study), but it was consistent that R_EFW was closer to the actual infant birth weight. ${ }^{6}$ From both study it was clear that Risanto formula to estimate fetal weight was closer to the actual infant birth weight compared to Johnson's regardless type of mothers, meaning that Risanto's formula was more accurate than Johnson's.

\section{CONCLUSION}

Risanto's formula is more accurate than Johnson's to estimate fetal weight in overweight mothers.

\section{REFERENCES}

1. Challis K, Osman NB, Nordahl G, Bergstro S. The Impact of Adjustment for Parity and Mid-UpperArm Circumference on Sensitivity of SymphysisFundus Height Measurements to Predict SGA Foetuses in Mozambique. 2003;8(2):2003. 
2. Kannieappan LM, Deussen AR, Grivell RM, Yelland L, Dodd JM. Developing a tool for obtaining maternal skinfold thickness measurements and assessing inter-observer variability among pregnant women who are overweight and obese. BMC Pregnancy Childbirth [Internet]. BMC Pregnancy and Childbirth; 2013;13(1):42. Available from: http://www.pubmedcentral. nih.gov/articlerender.fcgi artid $=3583701 \&$ tool $=$ pmcentrez\&rendertype=abstract

3. Neilson JP. Symphysis-fundal height measurement in pregnancy. Cochrane Database Syst Rev [Internet]. 2007;(4):CD000944. Available from: http://www.ncbi.nlm.nih.gov/entrez/query.fcgi? $\mathrm{cmd}=$ Retrieve\&db=PubMe $\mathrm{d} \& \mathrm{dopt}=$ Citation\&list_ uids $=10796225$

4. Khani S, Ahmad-Shirvani M, Mohseni-Bandpei MA, Mohammadpour-Tahmtan RA. Comparison of abdominal palpation, Johnson's technique and ultrasound in the estimation of fetal weight in Northern Iran. Midwifery. 2011;27(1):99-103.

5. Siswosudarmo R, Titisari I. Developing A New Formula for Estimating Birth. J Kesehat Reproduksi. 2014;1(2):145-9.

6. Titisari I, Siswosudarmo R. Risanto's Formulas is More Accurate in Determining Estimated Fetal
Weight Based on Maternal Fundal Height. Indones J Obs Gynecol. 2013;1(3):149-51.

7. Accu-Measure Personal Body Fat Caliper Q \& A Body Fat $Q$ \& A [Internet]. Available from: http://www.accumeasurefitness.com/uploads /5/0/4/3/50439275/accumeasure_fitness_3000_ instructions.pdf

8. Cunningham FG, Leveno $\mathrm{KJ}$, Bloom SL, Hauth JC, Rouse DJ, Y C. Williams Obstetrics. 23rd ed. New York: McGraw Hill Medical; 2010.

9. Numprasert W. A Study in Johnson's Formula: Fundal Height Measurement for Estimation of Birth Weight. Au JT. 2004;8(1):15-20.

10. Kopp-Hoolihan LE, van Loan MD, Wong WW, King JC. Fat mass deposition during pregnancy using a four-component model. J Appl Physiol (Bethesda, Md 1985). 1999;87(1):196-202.

11. Deeluea J, Sirichotiyakul S, Weerakiet S, Arora R, Patumanond J. Fundal height growth curve for underweight and overweight and obese pregnant women in Thai population. ISRN Obstet Gynecol [Internet]. 2013;2013:657692. Available from: http://www.pubmedcentral. nih.gov/articlerender. artid=3880769\&tool=pmcentrez\&rendertype $=a b$ stract 